\title{
Procedural Justice and Innovation: Does Procedural Justice Foster Innovative Behavior?
}

\author{
Bernhard Streicher ${ }^{1}$, Eva Jonas ${ }^{2}$, Günter W. Maier ${ }^{3}$, Dieter Frey ${ }^{1}$ \\ ${ }^{1}$ Department Psychology, Ludwig Maximilian University, Munich, Germany \\ ${ }^{2}$ Department Psychology, University of Salzburg, Salzburg, Austria \\ ${ }^{3}$ Department Psychology, University of Bielefeld, Bielefeld, Germany \\ Email: streicher@psy.lmu.de
}

Received September $25^{\text {th }}, 2012$; revised October 21 $1^{\text {st }}, 2012$; accepted November $22^{\text {nd }}, 2012$

\begin{abstract}
The influence of procedural justice on intended innovative behavior was studied in a sample of students and employees. Although earlier studies suggests that procedural justice increases innovation-related behavior such as spontaneous cooperation, so far systematic research is scarce. Results indicated that the provision of voice increased participants' intention to show innovative behavior such as task revision, creativity, and persistence in a business simulation task. Furthermore, the effects found were mediated by intrinsic motivation and identification, but not by occupational self-efficacy. These findings suggest that justice in organizations and procedural fair conditions in particular can drive innovations.
\end{abstract}

Keywords: Procedural Justice; Innovation; Task Revision; Creativity; Persistence

\section{Introduction}

In order to be successful, organizations depend heavily on cooperative behavior of their members (Kozlowski \& Ilgen, 2006). One important approach to ensure long term cooperative and committed behavior, is to organize a positive environment within an institution. One which fulfills the fundamental needs of its members. In particular, people value just and fair treatment. Fair treatment satisfies different human needs such as the need to belong and the need to control (cf. Van den Bos, 2005). Consequently, conditions of organizational justice and procedural justice, in particular, have become important situational variables in the psychological examination of both organizations and employees. Procedural justice focuses on the processes that lead to a decision outcome (Leventhal, 1980; Thibaut \& Walker, 1975), and provides the opportunity to voice one's opinion (e.g., Tyler, 2000). It has been found to influence different dimensions of work-related attitudes and behaviors such as job performance, spontaneous cooperation, job satisfaction, commitment, and organizational citizenship behavior (for overviews, see: Cohen-Charash \& Spector, 2001; Colquitt, Conlon, Wesson, Porter, \& Ng, 2001; Greenberg \& Colquitt, 2005).

In this article, we argue that conditions of procedural justice further enhance a specific form of cooperative behavior, which is crucial for all technical, economical, and social progress: the ability to behave innovatively (Amabile, 1988). Although several definitions of innovative behavior exist, the authors argue that during a process of innovation employees can show three aspects of individual innovative behavior. 1) Task revision: Employees recognize deficits, revise their given task in order to improve it, and feel competent about actually being able to realize the proposed changes. To do so, it may be necessary to voluntarily depart from daily routines and to follow up new ideas (Katz \& Kahn, 1978; Staw \& Boettger, 1990); 2) Creativity: The development and expression of new, creative ideas (cf Amabile, 1988); 3) Persistence: Persistently work on real- izing and implementing the innovation without being discouraged by set backs suffered.

Despite the lack of systematic research on the effects of procedural justice on innovative behavior, some studies have indicated a link between contiguous concepts of procedural justice and innovation-related behavior (e.g., between dignity/respect and cooperative behavior; Tan \& Tan, 2000; Tyler \& Blader, 2000), or showed a correlation between the two concepts (Gilson, 2001; Ramamoorthy, Flood, Slattery, \& Sardessai, 2005; Schepers \& Van den Berg, 2007), or demonstrated combined effects of justice and other constructs (outcome favorability and deception) on creativity (Clark \& James, 1999), or revealed a decline of creativity after repeated unfair treatment (Streicher, Jonas, Maier, Frey, \& Spiebberger, 2012). Overall, in light of previous studies, it is warranted to assume that procedural justice is associated with higher levels of innovative behavior and vice versa.

In addition to demonstrating a link from conditions of procedural justice to intended innovative behavior, this study aims to explore the mediating mechanisms. According to relational models, the fairness of procedure serves as a source of selfrelevant information on one's social status (Tyler, 1999). Fair treatment indicates a high status, and consequently people identify with their group or the authority (Tyler, 2000; Tyler \& Degoey, 1995). Moreover, if people identify with a group, they are intrinsically motivated to fulfill the group requirements (Tyler, 1997) such as to behave innovatively. In addition, intrinsic motivation is known to be an important source of innovation (Amabile, 1983, 1996). Regarding instrumental models (e.g. Thibaut \& Walker, 1975, 1978), people are motivated to maximize favorable outcomes, which they can obtain by controlling the relevant decisions. The fairness of procedure governs the amount of decision control on the outcomes. Decision control is the belief that one is able to influence processes in a preferred direction and corresponds with the concept of selfefficacy (Bandura, 1977, 1997). In accordance with these no- 
tions, research has found that individual innovative behavior can be positively correlated with continuance commitment with the organization (Zhou \& George, 2001), intrinsic motivation (Andrews \& Smith, 1996; Bunce \& West, 1995; Judge, Fryxell, \& Dooley, 1997; Shin \& Zhou, 2003; Tierney, Farmer, \& Graen, 1999), and self-efficacy (Axtell et al., 2000; Frese, Teng, \& Wijnen, 1999; Tierney \& Farmer, 2002).

In summary, we predict that procedural justice enhances intended innovative behavior, in contrast to conditions of procedural injustice, and that this effect is mediated by identification with the group, intrinsic motivation, and occupational selfefficacy.

\section{Method}

\section{Participants and Design}

A total of 70 people participated in this study, of which 36 were students (27 female, 9 male) and 34 were employees (18 female, 16 male). Students were approached in the university cafeteria, whereas employees were approached in suburban trains. Participants were randomly assigned to one of two conditions in a one-factorial (procedural justice: voice vs. no voice) between-subjects design. The design was balanced, with 34 participants in the voice and 36 in the no-voice condition.

\section{Procedure}

The experimenter approached the prospective participants and asked whether they would be prepared to read a business simulation case and to answer some question about it. If they agreed, the experimenter handed them the experimental material and a pen. No further instruction, cover story or reward was given. The experimental material consisted of a business simulation case followed by a questionnaire. The simulation, which was derived from a real case, described the situation of an engineer working on research and development in the steering wheels section of a car manufacturer. After consultations with his supervisor and beside his daily work he is free to develop his own ideas. One day he comes up with a new idea for the construction of a steering wheel for off-road vehicles. According to the company's rules he has to find an internal customer who will fund and approve his innovation. When he asks the rally sports division for funding, he learns that the operating devices section has had the same idea, and has already received funding and established a project team. Because the company does not want to support the same idea twice, he is asked to join the existing project team. At the request of the rally sports division he is invited to the next meeting. The manipulation of the independent variable (voice vs no voice) was realized through fair or unfair treatment by the project leader during the project team meeting (e.g. "You [are/are not] given the opportunity to voice your ideas by the project leader"; e.g. Van den Bos, Lind, Vermunt, \& Wilke, 1997).

Participants were asked to image the case to be real, and to answer the following questions (all ratings on a 5-point scale from $1=$ not at all to $5=$ very much) based on the feelings and reactions they would have if the situation were real. Potential mediators were measured as follows: intrinsic motivation (3 items adapted from Rheinberg, 1989; e.g. "I'm motivated to work as well as possible in the project team"; Cronbach's alpha $\alpha=.85$ ), occupational self-efficacy (4 items adapted from Schyns \& von Collani, 2002; e.g. "I remain calm when facing difficulties in the project team because I can rely on my abilities"; $\alpha=.78$ ), and identification ( 5 items borrowed from Mael $\&$ Ashforth, 1992; e.g. "I'm proud to be a member of the project team"; $\alpha=.95)$. Intended innovative behavior as the dependent variable was measured by 12 items $(\alpha=.92)$ representing the different aspects of innovative behavior, namely task revision (e.g. "I will reflect on how to further improve the existing idea for a new steering wheel"), creativity (e.g. "In the project team I will try to bring forward as many improvements as possible"), and persistence (e.g. "Even if there is no progress in the project team for some time, I will keep at it"). In accordance with Folger and Konovsky (1989) we used a mood assessment as a check for manipulation (PANAS; Watson, Clark, \& Tellegen, 1988), which comprised 10 items both for negative affects $(\alpha=.87)$ and for positive affects $(\alpha=.87)$. Participants answered the PANAS concerning their feelings about the project team ("How do you feel regarding the project team?").

\section{Results}

\section{Gender and Employment}

There was no effect of gender or status of employment (students vs. employees) on the dependent variables, all ts $<1.72$.

\section{Manipulation Check}

Between-subjects ANOVAs showed main effects for negative affects (NA), $F(1,68)=11.59, p<.01, \eta^{2}=.15$, and for positive affects (PA), $F(1,68)=21.63, p<.001, \eta^{2}=.24$. Participants who received voice had less negative affects $(M=1.89$, $S D=0.87)$ and more positive affects $(M=3.36, S D=0.76)$ than participants who had no voice (NA: $M=2.52, S D=0.70$; PA: $M=2.53, S D=0.74)$. These results indicate that we successfully manipulated procedural fairness.

\section{Innovative Behavior}

As predicted, a $t$-test revealed a significant difference between voice $(M=3.67, S D=0.69)$ and no voice $(M=3.11, S D$ $=0.67), t(68)=3.46, p<.01, d=0.69$, for intended innovative behavior. This result provides evidence supporting the hypothesis that procedural just treatment enhances innovative behavior compared to unfairness.

\section{Mediators: Identification, Intrinsic Motivation, Occupational Self-Efficacy}

In accordance with Baron and Kenny (1986) we checked first, (a) whether procedural fairness significantly accounted for the presumed mediators and the dependent variable. Separate regressions revealed that the procedural justice manipulation was predictive of inferences of identification, $\beta=.63, t(68)=6.64$, $p<.001$, as well as of intrinsic motivation, $\beta=.51, t(68)=4.92$, $p<.001$, occupational self-efficacy, $\beta=.34, t(68)=2.97, p$ $<.01$, and intended innovative behavior, $\beta=.39, t(68)=3.46, p$ $<.01$. Next (b) we controlled whether the potential mediators significantly accounted for the dependent variable. When examined simultaneously identification, $\beta=.73, t(68)=8.87, p$ $<.001$, as well as intrinsic motivation, $\beta=.71, t(68)=8.39, p$ $<.001$, and occupational self-efficacy, $\beta=.47, t(68)=4.42, p$ $<.001$, were predictive of inferences of intended innovative 
behavior. Last (c) we tested whether the relation between the independent and the dependent variable is reduced to non-significance when controlled by the mediators. When procedural justice, identification, intrinsic motivation, and occupational self-efficacy were examined simultaneously as predictors of intended innovative behavior the effects of both procedural justice, $\beta=.11, t(65)=1.10, p>.27$, and occupational selfefficacy, $\beta=.08, t(65)=0.70, p>.48$, were reduced to nonsignificance whereas the effects of both identification, $\beta=.48$, $t(65)=2.24, p<.05$, and intrinsic motivation, $\beta=.40, t(65)=$ $2.69, p<.01$, remained significant. The results provide evidence that the procedural justice effect on intended innovative behavior was mediated by identification and intrinsic motivetion, but not by occupational self-efficacy. Furthermore, to test whether both identification and intrinsic motivation carry the influence of procedural justice to intended innovative behavior we conducted Sobel tests (Sobel, 1982). The results confirmed the mediation and showed that the indirect effects of procedural justice on intended innovative behavior via identification, $z=$ $5.00, p<.001$, as well as via intrinsic motivation, $z=4.04, p$ $<.001$, were significantly different from zero.

\section{Discussion}

As predicted, conditions of procedural justice resulted in more intended innovative behavior than procedural unjust conditions. This result supports the notion that a positive, appreciating, and participating organizational practice fosters cooperative, voluntary, and constructive employee behavior. Furthermore, the findings provide evidence for relational model's line of reasoning concerning the nature of the mediation of procedural justice effects. Whereas intrinsic motivation and identification are both potent mediators, occupational self-efficacy is not. The underlying reason could be (a) that procedural just treatment, as self-relevant information, increases identification with the group and/or supervisor as well as intrinsic motivation to meet group and/or organizational goals such as innovative behavior. This argument provides support for relational models of procedural justice but not for instrumental models. Our result that self-efficacy did not serve as a mediator is in accordance with earlier research which also found no or only a partial mediating effect of process control (Earley \& Lind, 1987; Lind, Kanfer, \& Earley, 1990; Shapiro \& Brett, 1993). However, another reason (b) for our findings might stem from the more general belief in personal competence: Occupational self-efficacy may be a more stable trait, which is unlikely to be influenced by a single scenario. On the other hand, this explanation seems improbable considering that Lind and colleagues (1990) have found participants' belief in having decision control to be affected by conditions of procedural justice, even when participants only received voice after the decision and were told that their opinion would not influence the decision.

The findings in this study are subject to at least three limitations. First, one weakness is that suggested treatment within a business simulation might be of lower personal importance to participants than real treatment by a supervisor at the workplace would be. Therefore, so far the external validity of our findings is not warranted. Second, the results are reactions of individuals, but in organizational practice innovative behavior occurs within a social context (cf. Amabile, Conti, Coon, Lazenby, \& Herron, 1996). Therefore, future investigations on this topic should consider additional context variables such as organizational climate or quality of leader-member-relation. Third, cognitive and motivational variables were measured as potential mediators, but research suggests that experiences of justice provoke positive emotions such as pride while injustice comes along with negative emotions like anger, disappointment, fear, or sadness (e.g., Weiss, Suckow, \& Cropanzano, 1999). In order to fully understand the nature of the mediating mechanisms it is recommended to conduct longitudinal field studies, which cover the full process of an innovation, and include a broad selection of emotional, motivational, and cognitive mediators.

Overall, besides the practical importance of innovations, our findings demonstrate the wide range of positive justice effects on peoples' attitudes and behavior. People are sensitive to experiences of fairness and unfairness, and adjust their behavior to their experiences accordingly. Therefore, in order to increase both the wellbeing of their members and innovativeness as a crucial factor in global competition organizations should be alert to maintain procedural just condition. A positive institution in this sense can be reached by implementing fair procedures and decision-making processes, and by training leaders in justice principles.

\section{Acknowledgements}

The German Research Foundation (DFG) financed part of this work (project number FR 472/24-1), but had no involvement in the conduct of this research.

\section{REFERENCES}

Amabile, T. M. (1983). The social psychology of creativity. New York: Springer. doi:10.1007/978-1-4612-5533-8

Amabile, T. M. (1988). A model of creativity and innovation in organizations. In B. M. Staw, \& L. L. Cummings (Eds.), Research in organizational behavior (Vol. 10, pp. 123-167). Greenwich, CT: JAI Press.

Amabile, T. M. (1996). Creativity in context. Update to the social psychology of creativity. Boulder, CO: Westview.

Amabile, T. M., Conti, R., Coon, H., Lazenby, J., \& Herron, M. (1996). Assessing the work environment for creativity. Academy of Management Journal, 39, 1154-1184. doi:10.2307/256995

Andrews, J., \& Smith, D. C. (1996). In search of the marketing imagination: Factors affecting the creativity of marketing programs for mature products. Journal of Marketing Research, 33, 174-187. doi: $10.2307 / 3152145$

Axtell, C. M., Holman, D. J., Unsworth, K. L., Wall, T. D., Waterson, P. E., \& Harrington, E. (2000). Shopfloor innovation: Facilitating the suggestion and implementation of ideas. Journal of Occupational and Organizational Psychology, 73, 265-285.

doi:10.1348/096317900167029

Bandura, A. (1977). Self-efficacy: Toward a unifying theory of behavioral change. Psychological Review, 84, 191-215. doi:10.1037/0033-295X.84.2.191

Bandura, A. (1997). Self-efficacy: The exercise of control. New York: Freeman.

Baron, R. M., \& Kenny, D. A. (1986). The moderator-mediator variable distinction in social psychological research: Conceptual, strategic, and statistical considerations. Journal of Personality and Social Psychology, 51, 1173-1182. doi:10.1037/0022-3514.51.6.1173

Bunce, D., \& West, M. A. (1995). Self perceptions and perceptions of group climate as predictors of individual innovation at work. Applied Psychology: An International Review, 44, 199-215. doi:10.1111/j.1464-0597.1995.tb01076.x

Clark, K., \& James, K. (1999). Justice and positive and negative creativity. Creativity Research Journal, 12, 311-320.

doi: $10.1207 / \mathrm{s} 15326934 \mathrm{crj} 12049$ 
Cohen-Charash, Y., \& Spector, P. E. (2001). The role of justice in organizations: A meta-analysis. Organizational Behavior and Human Decision Processes, 86, 278-321. doi:10.1006/obhd.2001.2958

Colquitt, J. A., Conlon, D. E., Wesson, M. J., Porter, C. O. L. H., \& Ng, K. Y. (2001). Justice at the Millennium: A meta-analytic review of 25 years of organizational justice research. Journal of Applied Psychology, 86, 425-445. doi:10.1037/0021-9010.86.3.425

Earley, P. C., \& Lind, E. A. (1987). Procedural justice and participation in task selection: The role of control in mediating justice judgments. Journal of Personality and Social Psychology, 52, 1148-1160. doi:10.1037/0022-3514.52.6.1148

Folger, R., \& Konovsky, M. K. (1989). Effects of procedural and distributive justice on reactions to pay raise decisions. Academy of Management Journal, 32, 115-130. doi:10.2307/256422

Frese, M., Teng, E., \& Wijnen, C. J. D. (1999). Helping to improve suggestion systems: Predictors of making suggestions in companies. Journal of Organizational Behavior, 20, 1139-1155. doi:10.1002/1099-1379.20.7

Gilson, L. L. (2001). The role of procedural justice in the relationship between demographic diversity, dissimilarity, work-related affective outcomes, and creative performance. Unpublished Dissertational Thesis, Atlanta, GA: Georgia Institute of Technology.

Greenberg, J., \& Colquitt, J. (2005). Handbook of organizational justice. Mahwah, NJ: Lawrence Erlbaum Associates.

Judge, W. Q., Fryxell, G. E., \& Dooley, R. S. (1997). The new task of R\&D management: Creating goal-directed communities for innovation. California Management Review, 39, 72-85.

Katz, D., \& Kahn, R. L. (1978). The social psychology of organizations. New York: Wiley.

Kozlowski, S. W. J., \& Ilgen, D. R. (2006). Enhancing the effectiveness of work groups and teams. Psychological Science in the Public Interest, 7, 77-124.

Leventhal, G. S. (1980). What should be done with equity theory? New approaches to the study of fairness in social relationships. In K. J. Gergen, M. S. Greenberg, \& R. H. Willis (Eds.), Social exchange: Advances in theory and research (pp. 27-55). New York: Plenum. doi:10.1007/978-1-4613-3087-5_2

Lind, E. A., Kanfer, R., \& Earley, P. C. (1990). Voice, control, and procedural justice: Instrumental and noninstrumental concerns in fairness judgments. Journal of Personality and Social Psychology, 59, 952-959. doi:10.1037/0022-3514.59.5.952

Mael, F., \& Ashforth, B. E. (1992). Alumni and their alma mater: A partial test of the reformulated model of organizational identification. Journal of Organizational Behavior, 13, 103-123. doi:10.1002/job.4030130202

Ramamoorthy, N., Flood, P. C., Slattery, T., \& Sardessai, R. (2005). Determinants of innovative work behaviour: Development and test of an integrated model. Creativity and Innovation Management, 14, 142-150. doi:10.1111/j.1467-8691.2005.00334.X

Rheinberg, F. (1989). Purpose and occupation. In F. Rheinberg (Ed.), Zweck und tätigkeit (pp. 61-161). Göttingen: Hogrefe.

Schepers, P., \& Van den Berg, P. T. (2007). Social factors of workenvironment creativity. Journal of Business and Psychology, 21, 407-428. doi:10.1007/s10869-006-9035-4

Schyns, B., \& von Collani, G. (2002). A new occupational self-efficacy scale and its relation to personality constructs and organizational variables. European Journal of Work and Organizational Psychology, 11, 219-241. doi:10.1080/13594320244000148

Shapiro, D. L., \& Brett, J. M. (1993). Comparing three processes underlying judgements of procedural justice: A field study of mediation and arbitration. Journal of Personality and Social Psychology, 65, 1167-1177. doi: 10.1037/0022-3514.65.6.1167
Shin, S. J., \& Zhou, J. (2003). Transformational leadership, conservation, and creativity: Evidence from Korea. Academy of Management Journal, 46, 703-714. doi:10.2307/30040662

Sobel, M. E. (1982). Asymptotic intervals for indirect effects in structural equations models. In S. Leinhart (Ed.), Sociological methodology 1982 (pp. 290-312). San Francisco: Jossey-Bass.

Staw, B. M., \& Boettger, R. D. (1990). Task revision: A neglected form of work performance. Academy of Management Journal, 33, 534-559. doi: $10.2307 / 256580$

Streicher, B., Jonas, E., Maier, G. W., Frey, D., \& Spießberger, A. (2012). Procedural fairness and innovation: Does voice promote people's creative vein? Creativity Research Journal. doi: $10.1080 / 10400419.2012 .730334$

Tan, H. H., \& Tan, C. S. F. (2000). Toward the differentiation of trust in supervisor and trust in organization. Genetic, Social, and General Psychology Monographs, 126, 241-260.

Thibaut, J. W., \& Walker, L. (1975). Procedural justice: A psychological analysis. Hillsdale, NJ: Erlbaum. doi:10.2307/3480099

Thibaut, J. W., \& Walker, L. (1978). A theory of procedure. California Law Review, 66, 541-566. doi:10.2307/3480099

Tierney, P., \& Farmer, S. M. (2002). Creative self-efficacy: Its potential antecedents and relationship to creative performance. Academy of Management Journal, 45, 1137-1148. doi:10.2307/3069429

Tierney, P., Farmer, S. M., \& Graen, G. B. (1999). An examination of leadership and employee creativity: The relevance of traits and relationships. Personnel Psychology, 52, 591-620. doi:10.1111/j.1744-6570.1999.tb00173.x

Tyler, T. R. (1997). The psychology of legitimacy. Personality and Social Psychology Review, 1, 323-345. doi:10.1207/s15327957pspr0104_4

Tyler, T. R. (1999). Why people cooperate with organizations: An identity-based perspective. Research in Organizational Behavior, 21, 201-246.

Tyler, T. R. (2000). Social justice: Outcome and procedure. International Journal of Psychology, 35, 117-125. doi: 10.1080/002075900399411

Tyler, T. R., \& Blader, S. L. (2000). Cooperation in groups: Procedural justice, social identity, and behavioral engagement. Philadelphia: Psychology Press.

Tyler, T. R., \& Degoey, P. (1995). Collective restraint in social dilemmas: Procedural justice and social identification effects on support for authorities. Journal of Personality and Social Psychology, 69, 482-497. doi:10.1037/0022-3514.69.3.482

Van den Bos, K. (2005). What is responsible for the fair process effect? In J. Greenberg, \& J. Colquitt (Eds.), Handbook of organizational justice (pp. 273-300). Mahwah, NJ: Lawrence Earlbaum.

Van den Bos, K., Lind, E. A., Vermunt, R., \& Wilke, H. A. M. (1997). How do I judge my outcome when I do not know the outcome of others? The psychology of the fair process effect. Journal of Personality and Social Psychology, 72, 1034-1046. doi: $10.1037 / 0022-3514.72 .5 .1034$

Watson, D., Clark, L. A., \& Tellegen, A. (1988). Development and validation of brief measures of positive and negative affect: The PANAS scales. Journal of Personality and Social Psychology, 54, 1063-1070. doi:10.1037/0022-3514.54.6.1063

Weiss, H. M., Suckow, K., \& Cropanzano, R. (1999). Effects of justice conditions on discrete emotions. Journal of Applied Psychology, 84, 786-794. doi:10.1037/0021-9010.84.5.786

Zhou, J., \& George, J. M. (2001). When job dissatisfaction leads to creativity: Encouraging the expression of voice. Academy of Management Journal, 44, 682-696. doi:10.2307/3069410 